\title{
Separating Culture from Institutions: The Use of Semantic Spaces as a Conceptual Domain and the Case of China
}

\section{Gordon Redding}

INSEAD, France

ABSTRACT The analysis of societies, and of systems of business within them, has tended to be heavily influenced by institutionalist perspectives. Many scholars using this approach include culture as a subset of institutions, but often without specifying the logics of doing so. Others remove culture from the account, or acknowledge its significance without placing it clearly in their models. Culturalists, however, tend not to venture into the details of economic coordination and action. To resolve the theoretical challenges posed by this set of contrasting views, it is necessary to specify how culture works and how it is different from institutions. As 'the societal effect' is the influence of culture on institutions, it may thus be easicr to study its workings. Here culture is seen, following Sorge, as meaning relevant within a series of semantic spaces, each related to a field of action, the total integrated coherently by social axioms binding the spaces and the meanings within them into a total societal fabric of meaning. The private sector of the Chinese economy is analysed, drawing from recent extensive empirical reports as to its functioning. Theory development is in line with business systems theory.

KEYwORDs business systems, China, culture, institutions, semantic spaces

\section{INTRODUCTION}

There are three problems in explaining the role of culture in economic life: (i) culture becomes tangled up with institutions in many accounts; (ii) it is ignored or discounted by many economists; and (iii) culture specialists tend to remain within a tight arena of their own, measuring culture usually via values, but examining inadequately what it does in the economy and how. I propose some alleviation of these research dilemmas by outlining a way of separating culture from institutions while showing how they interact to produce (in most cases) coherent economies and societies. This societal effect cannot be fully understood unless its components are identifiable and consequently analysable in terms of their workings. To illustrate the ideas at work, I use the culture of China's private sector businesses, making an assumption that this now dominant subculture of the Chinese economy 
has enough internal stability and coherence to be identifiable, even though it will inevitably contain variety in the finer details.

The eventual question at issue is the effect of culture on economic behaviour and, especially, on two aspects of that behaviour: the patterns of managerial and organizational response that stabilize and become 'normal' within a culture; and the ways in which the culture may influence economic performance. These larger questions are discussed at an introductory level in the conclusion. More detailed addressing of them is a major and separate set of projects. The paper's approach is multi-disciplinary.

I do not contend that culture is necessarily per se a dominant determinant of events but that it is significant and deserves a place in its own right, especially for its role as the provider of meaning in the shaping of institutions. I propose a way of providing for this role of culture, taking account of interpretive thinking and using the notion of spaces of social action inside which distinct meanings accumulate. These I call semantic spaces. I see culture as qualitatively different from institutions and, although reciprocally connected with them, still, in some simple sense, prior. I will provide here a definition that will be subject to elaboration in the remainder of the paper. Hence, 'culture' is shared meaning relevant within a series of semantic spaces, each related to a field of action, the societal total being integrated, with varying degrees of coherence, by social axioms binding the spaces and meanings within them into a total societal fabric of meaning. 'Institutions' are specific enacted rulc-sets interpreting the meanings into action, applied within the spaces and sometimes across them.

The paper is written within the field of socioeconomics and following work such as that of Whitley (1992, 1999a, 2002) on business systems, of Guillen (1994) on the interplay between modes of thought and institutional circumstances in producing societally different models of management and of Biggart and Delbridge (2004) on culturally distinct systems of exchange deriving from differently constructed social worlds. The ghost of Max Weber stands in the background.

The paper proceeds with a conceptual discussion of these issues. I begin by pointing out the research challenges in explaining culture and current thinking on 'the societal effect'. I then proceed with a detailed discussion of the notion of 'semantic spaces', distinguishing culture from institutions and the role of social axioms. I apply these ideas to the example of the private sector in the Chinese context. The paper ends with a discussion of the implications for theory and future research.

\section{CONCEPTUAL DISCUSSION}

\section{Research Challenges in Explaining Culture}

Three categories of researchers have tended to dominate the enquiries into the major qucstions about how economies reflect societies and why economic 'success' 
is unevenly distributed. (I leave out of consideration those who believe, like many economists, that one set of social behaviour laws applies universally.)

Category 1. Culture as measured values. Understandably - given the nature of academic specialism - those who concentrate on culture tend to be disengaged from researching institutions and economic behaviour, except in the more obvious (and notionally measurable) domains of organizational behaviour such as leadership style. As recently noted by Gelfand, Nishii and Raver (2007) and Tsui, Nifadkar and Ou (2007), cross-cultural research has been dominated by the values paradigm and more complete view is needed. There are always exceptions, but in a review of the literature conceptualizing culture, Boyacigiller, Kleinberg, Phillips, and Sackman (1996, p. 11) pointed out that 'the kind of thick descriptions, focusing on process and emergent culture, that are necessary to understand not just where and when but how culture influences behaviour have rarely been attempted within the dominant international cross-cultural management paradigm'. At a recent global conference on culture, hosted by the Institute of International Business of the Stockholm School of Economics (http://www.hhs.se/IIB/ConferencesAndWorkshops), the dominance of the quantitative paradigm became obvious and so too its self-replicating nature. Calls were made (as they have been for decades, e.g., Barrett \& Bass, 1976; Boyacigiller \& Adler, 1991; Child, 1981, 2000; Redding, 1994; Roberts, 1970; Triandis, 1992) for a breaking away from the entrenched normal science of the discipline.

Category 2. Institutions as the prime focus. Those who concentrate on institutions tend to be disengaged from researching their origins in meaning systems and often prefer to lump all societal determinants together as institutions of one kind or another. Among many of them, there is a reluctance to deal with culture. The issue for the social sciences has been brought to the fore by recent treatments of the question by major institutional theorists. Economic historian Douglass North - the originator of much of the institutional theory in current use - has recently developed his long-standing and influential interest in the role of institutions in economic development by specifically acknowledging the role of culture and the significant consequent of culture that he terms 'intentionality' - the conscious attempts of people to shape their futures. He identifies the significance of our genetic architecture, and of religious underpinnings, but states that

Culture not only determines societal performance at a moment in time but, through the way in which its scaffolding constrains the players, contributes to the process of change through time. (North, 2005, p. viii)

He also makes clear his belief that humans construct elaborate beliefs about the reality surrounding them and that these beliefs are both descriptive of how the system works and normative with respect to how it should work. The dominant 
beliefs, and especially those of political and economic entrepreneurs, 'over time result in' the accretion of an elaborate system of institutions (North, 2005, p. 2, my italics).

North unequivocally sees culture (along with genetics and religion) as 'central to the performance of economies and polities over time' (2005, p. ix). With equal force, he accuses economics - a discipline based on a theory of choice - of neglecting to explore the context within which choice occurs. Kogut's (2003) related challenge to international business theory, viz. to deal with context, has been taken up elsewhere by Redding (2005). A parallel theory, by Greif (2006), accepts North's challenge and argues that institutions comprise four elements working together in a system. He proposes that

Institutions are not monolithic entities but are composed of interrelated but distinct components, particularly rules, beliefs, and norms, which sometimes manifest themselves as organizations. These institutional elements are exogenous to each individual whose behaviour they influence. (Greif, 2006, p. 14)

Greif's work is founded in the use of game theory to establish the equilibria achieved with the mixing of the institutional elements and their surroundings - in different contexts - to foster economic stability and perhaps progress. Although his findings are based in the mediaeval worlds of the Islamic Mediterranean and Western Europe, the case he makes has powerful resonance for the modern world. His accounting for the way in which collectivism leads to 'segregated' societies, and individualism to more 'integration', allows an understanding of many resulting structures and behaviour patterns (Greif, 1994). Note, however, that he includes beliefs and norms within the category of institutions. An opening up of the question of how the rules, beliefs and norms 'manifest themselves as organizations' would appear justified, as such processes may not be fully explicable within the equilibria of closed-system game theory, given the open system nature of much social life and the subterranean influences of alternative meanings, an outcome of which is that categories used in analysis may mean different things to different actors. There is no ontological reality out there independent of meaning - a severe challenge for economics (Whitley, 1999a,b).

Category 3. Grand theory. Few scholars inhabit this no-man's-land in social science between culture and institutions - comfortably. The tracks across it are few and far between, by which I mean that the linkages of determinacy between the two realms are not clearly known. There is in this terrain what Sorge (2005, p. 48) terms 'a mountain of theoretical muddle' and the need for a clearer way of generating research questions and explanations. How does culture influence the shaping of institutions? How do institutions, in reverse, shape culture? Are the two realms in fact different, and if so, where does one end and the other begin? Or are they essentially the same thing? Those who have attempted these questions (e.g., 
DiMaggio \& Zukin, 1990; Eisenstadt, 1968; Inglehart \& Welzel, 2005; Williamson, 1994) have achieved great progress in establishing categories for analysis and evidence of effects. But there remain questions as to the mechanics of the process, for the understanding of which new methods may be justified. Much also needs to be done to achieve agreement on the appropriate determinants to use.

Those intent from the outset to take on the entire spectrum of socioeconomics, from Weber onwards, have tended to engage in especially complex accounts. We see here a smorgasbord of prime causes: examples among many are the collective mindset (Weber, 1930), the societal change process (Eisenstadt, 1968, 1996), the social capital endowment (Fukuyama, 1995), the historical legacy (Landes, 1998), the economic policies (Stiglitz, 2002). I now turn to see how scholars are currently meeting the challenge of integrating these rich contributions.

\section{Current Thinking on 'the Societal Effect'}

The central issue addressed here is elsewhere termed 'the societal effect', and it has received increasing attention from scholars analysing variations in societal 'progress' (e.g., Fligstein, 2001; Himmelfarb, 2004; Landes, 1998; Pomeranz, $2000)$. Its connection with patterns of economic action has been at the core of theorizing, since the early - but still hardly surpassed - work of Weber (1927, 1930). Recent attention to comparative systems of business has brought it again to the fore but rarely in a way that permits the tracing of clear patterns of connection between culture as the realm of meaning and interpretation (e.g., Geertz, 1973) and institutions as rules of the game in the field of social action (e.g., North, 1991). There is a realm of shared meanings, and there is a realm of 'scaffolding' providing order. How one connects with the other is not yet analysed in a way that a wide range of scholars can agree upon. As Gelfand et al. (2007, p. 15) state it, 'A key challenge for culture scholars is to propose and validate dimensions of societal institutions and link these to dimensions of culture' (original emphasis).

At the highest level of attempted explanation of variations in socictal economic progress, that of societies compared globally and historically, Landes (1998, p. 516) concluded that 'If we learn anything from the history of economic development, it is that culture makes all the difference'. At a similar level, Fukuyama (1995) identified trust as the crucial centrepiece of the social virtues that allowed societies to develop materially. Inglehart (2000) has shown the correlations of per capita wealth - with both trust and (at a different level of analysis) religion. Echoing this, McCloskey (2006) has specified the 'bourgeois virtues' leading to progress. Harrison (1985) proposed in his book title that underdevelopment is a state of mind and has since added major new findings to substantiate his argument and to identify the obstacles to development (Harrison, 2006). The massive empirical studies of comparative culture (Hofstede, 1980, 1991; House, Hanges, Javidan, Dorfman, \& Gupta, 2004; Inglehart, 1997; Leung \& Bond, 2004; Schwartz, 1994) 
provide consistent and ample confirmation of cultural contrasts. A number of scholars have made major contributions to the challenge of explaining the linkages from meaning to social action, noteworthy examples being Berger and Luckmann (1966) on the social construction of reality, Stinchcombe (1974) on Latin America, Foster (1967) on the mental world of peasant existence, and Giddens (1984) on structuration, but we are still missing a widely adopted framework capable of uniting research programs.

By this I mean that, after the first step of delineating the contrasts in values and norms, the next steps are not obvious and are rarely taken. There are inputs in the form of values, and there are outcomes in the form of behaviour patterns and economic structures, but the middle connections remain locked in a black box.

Those who assume that convergence will solve the problem of the contrasts eventually run up against two connected difficulties. The first is that much of the difference plays out its effects at the subconscious or pre-conscious level. Clark Kerr, who was instrumental in originating the idea of convergence (Kerr, Dunlop, Harbison, \& Myers, 1960), decades later revised his view and warned that although convergence took place to some degree, alternative societal systems eventually began to run along parallel, non-converging lines. In this revised view, he made a crucial distinction between the realm of everyday life and the realm of the mind, observing that things might appear to converge in the former, but showed little sign of doing so in the latter (Kerr, 1983). The factories and offices of different societies might look the same at first glance, but as to how they functioned were, in significant ways, still different. The meanings of behaviour remained divergent. A recent study of employment practices in Korean firms located in the UK (Glover \& Wilkinson, 2007) concluded that the successful practical blending of systems required access to two different sets of meanings about work (see e.g., Bond, 1996, and especially Yang, 1986, for the Chinese case, and Witt, 2006, for the Japanese case). The idea of 'cross-vergence' (Ralston, Holt, Terpstra, \& Cheng, 1997) addresses this issue with practical advice and reveals the complexity of the challenge for practitioners.

Taking the society's business system, or 'system of capitalism' as its explanandum, a literature is growing rapidly that provides explanatory frameworks for the continuing variety (c.g., Dore, 2000; Fligstein, 200 I; Guillen, 1994, 2001; Hall \& Soskice, 2001; Hollingsworth \& Boyer, 1997; Redding, 2005; Sorge, 2005; Whitley, 1992, 1999a,b, 2002). The tendency in this literature is either to deal sociologically with institutions as the explanatory core or to deal at the level of political economy with macro-structures in the society. So far, little of this work has dealt specifically with systems of meaning as being - in some crude sense - 'prior' to the more visible institutions such as labour market or capital market structures. Arguably the most sophisticated of these formulations - that of Whitley - acknowledges clearly the roles of trust and authority relations but does not deal with them as cultural features, except by subsuming culture under institutions. 
There are certain specific attempts to introduce issues of 'meaning' into the account, as for instance with Fligstein's (2001) notion of the 'conception of control' influencing organizational responses, Guillen's (2001) discussion of mental universes shared by key actors across a societal economy and Biggart and Delbridge's (2004) presentation of contrasting rationales in systems of exchange. So too has Sorge $(2005$, p. 47 ) identified 'action systems' (where actors in a social space, such as an employment relationship, share a common set of meanings) as a crucial input to the explanation of distinct societal business systems. Schumpeter (1976, p. 130) perceptively noted the significance of 'the choosing mentalities' of economic actors, echoing the foundation work of Weber in his analysis of varying forms of rationality. The latter's core assumption - of the specific and peculiar nature of Western rationality - in other words its distinct interpretation of ends and means continues to remind us that the conduct of international business crosses more boundaries than just the geographical and more disciplines than just the economic.

Perhaps the most relevant of the above approaches for the argument in this paper is that of Biggart and Delbridge (2004) in their exploration of alternative 'systems of exchange'. In this, they argue that deviations from the perfect market should not be seen as imperfections, nor social relations scen as friction. Instead, they are reflections of culturally constructed social worlds, each with its distinct orientation to economic action. Drawing on the earlier work of DiMaggio and Zukin, they see culture working via four processes: influencing how actors define their interests; constraining peoples' efforts on their own behalf; shaping a group's capacity to mobilize; and shaping the purposes of such mobilizing. A society is seen as a set of domains, such as family, polity, economy. Each has its own fundamental logics of action - its goals, strategies, and bases for evaluation. A culture is then a 'finite set of context-dependent orientations and a set of rules for switching among them' (1990, p. 31). Economies then come to contain 'exchange arenas' that are not necessarily vestiges of pre-modern or ethnic enclave systems, but rather are workable responses to context. They do not need to develop into something more 'proper' or more 'advanced'. The world displays choices over how efficient markets are created.

I turn now to examine how such 'arenas', 'spaces', or 'domains', may be thought about in greater detail.

\section{The Notion of Semantic Spaces}

Biggart and Delbridge's (2004) 'domains', each with its logics of action, bring to mind the parallel idea of Sorge (2005) that he terms 'action systems'. He explains that, following the original formulation of the idea by Luhmann, they were commonly referred to in French as espaces, or spaces. Inside one of these, a particular form of action occurs, such as eating, or working in a factory, or going to a temple. These are envelopes in which aspects of the culture may be placed. In a similar way, Fligstein (2001) has proposed the dividing of markets into 'fields' coinciding 
with particular product markets, each with its own structure and hierarchy. I propose to retain the original 'spaces' metaphor in the term used here and to add to it the factor of shared meaning, thus 'semantic spaces'. The special value of this idea lies in its ability to help deal with the complexity within a society, but more particularly to deal with the distinction between culture and institutions.

Societal complexity becomes possible when specific groups see most of their world differently because of specialization, but enough of their world similarly for them to co-exist and cooperate. Some meanings are widely shared in the society; thus, most citizens share an understanding of what is normal to eat and how to do so. Other meanings are restricted to certain groups; thus, only universities are concerned with postgraduate degree work, with all its special vocabulary and priorities. The world of unions is very largely the world of subgroups of employees.

The sharing of meaning thus clusters around a field of coordinated action. For example, a whole group of people, concerned with the allocation of capital in the society, share the vocabulary (and so the meaning) of investment. They work in banks, investment firms, accounting houses, research institutes, professional bodies, and ministries. They talk their own technical language, discussing such things as ROI, PBIT, syndication, hedge funds, floats, overnight rates, etc. in ways that unite them, not just in the sharing of definitions, but in the assigning of significance, procedural knowledge and the coordinating of action. So, if news arrived that the yuan had been floated, the significance (i.e., the meaning of the fact in its context) would be immediately understood - in terms of the implications for their individual actions - by all members of the 'allocation of capital' semantic space. In such a semantic space, those inside it share actions of the same type - thus, in the above case, they all get involved in the sourcing and allocating of capital. They also share the understanding of what is going on, both as perceived facts and generally shared interpretation. The meanings of things and events within the space are common, and hence, its unity is semantic. It is also a field; in other words, it contains a centre of gravity and layers of belonging or membership, such that a bond trader or a corporate finance officer would be deeply embedded in it, and a family lawyer only partially. In Ragin's (2000) term it is a fuzzy set, having floating membership around a core. Members have in varying degrees acquired the language of the space and the frameworks of understanding that go with that language.

In an important departure from the earlier version of the idea by Luhmann, Sorge (2005, p. 47) proposes that, in societal analysis, these spaces be seen not as drifting apart with modernization into zones of autonomous meaning, but instead as remaining elements in a coherent whole, that whole being the overarching societal culture. In this respect, their specialized meaning structures can be transmitted across the whole, via linkages. So, an investment advisor might act as a link between the space of highly technical investment performance analysts and the space of the housewife sitting across the table in a bank seeking advice on where to put the family savings. The bankers need to understand the meaning of savings in 
a household, and the housewife needs to understand about yield, risk, equities, bonds, etc. Meanings become integrated across the society as people learn to interpret the special vocabularies and as their needs for action take them in and out of the various spaces.

The same applies across types of job. A management trainee learning to understand a general management perspective may be exposed through periods of assignment to the 'spaces' of marketing, finance, personnel, corporate affairs, etc., in the expectation that he or she will create a linked and integrated view of the whole, that itself being a new space inhabited by a group of people socialized into understanding general management. Clearly in this view the spaces overlap and interpenetrate, a point to which I will return.

There is a clear connection here with the discussion of socialization in the Berger and Luckmann (1966) theory of socially constructed reality. In this, a process of primary socialization provides the individual with what I shall later, following Bond, Leung, Au, Tong, de Carrasquel, Murakami et al. (2004), refer to as social axioms - the basic understandings of how society works - but then the individual goes through secondary socialization. In this, the person specializes in making sense of particular fields, each with its own vocabulary, accumulating a possibly large number of these, but probably 'inhabiting' one in earning a living and in finding meaning in life. The number of such spaces in a society can be very large, but they remain integrated by having the core axioms running though them.

\section{Distinguishing Culture from Institutions}

If a person constructs reality by accumulating and integrating clusters of meaning in semantic spaces, and if the total of these clusters becomes his or her culture, the sum of such individual mindsets being the societal culture, the question now is where do we fit institutions, and how do they differ from that culture?

Let me begin with Sorge's (2005, p. 48) definition of the difference (noting again that his term is 'action systems', not spaces):

The main difference between action systems and institutional entities is that action systems have precisely the same meaning in mind although they do not have people who actually belong to them, whilst institutional entities are coordinated, governed, and endowed with people who are clearly members. Thus we each belong only to a small number of institutional entities, but to a large number of action systems, although we are not consciously aware of these.

The distinction being made here is crucial. Semantic spaces act as places where meanings are 'stored', i.e., consensually conditioned, and relevant to action. Because such spaces are the repositories of collectively agreed meaning, they can transcend the limitations of their members' temporary presence, even their 
members' deaths. They can also transcend the changes taking place in the institutional interpretation of meaning. To take an example, the Chinese ideal of paternalism, a core meaning cluster within the institution of family, was not destroyed in the Mao era, even though the commune system was deliberately designed to undermine the family institution itself and replace it with communal living (Becker, 1996; Guthrie, 2006). Family separations, the arrival of female equality, one-child families, and national campaigns against the 'four olds' of Confucianism could not over decades remove the instincts of millennia. Paternalism subsequently returned, along with a re-designed family institution, and continues to play its part in the changing social context of China (Feng \& McDonough, 2006; Huang, Van der Vliert, \& Van der Vegt, 2005). It is as if the culture is at a deep layer, the result of what Berger and Luckmann called 'sedimentation' - the long slow accretion of meanings; and institutions are at the surface.

In each of the semantic spaces, people spend time doing things on the basis of shared understandings about what is and should be happening, cued to the appropriateness of those understandings by the locale or even the name of the institution. So eating at McDonalds yields different meanings and responses from those during 'fine dining' in the grill room of a five star hotel. Peoples' behaviour is heavily conditioned by such understandings. When that behaviour stabilizes into fixed patterns, so becoming 'rules of the game' or norms, and when people make social structures to operate those rules, then you have institutions.

Sorge (2005, p. 49) employs a useful simile to illustrate the different nature of collectively held meanings and institutions. It is as if society were a large building with social life conducted by people moving between rooms and in each room some specific kind of action takes place. People enter the room to do something using the commonly agreed meanings surrounding that action. Over time they bring furniture into the room to stabilize the pattern of action, as when a round dining table confirms communal eating, or a pattern of seating defines hierarchy. The furniture is the set of institutions. The choice of what furniture to use is affected by the meanings that need converting into action. When an institution, i.e., a piece of furniture, needs changing it can be taken out and replaced. Without the furniture, the rooms are blank and inhibit action. Without the meanings, the furniture just gets in the way.

But the congruence of the world of ideas with the world of order is not perfect, and this, above other considerations, justifies their separation in analysis. It could be argued that all institutions start as ideas and that the most effective institutions are grounded in ideas seen as worth adhering to. As Streeck (1997) has pointedly observed (p. 209) 'A bad society is incapable of sustaining a good economy'. But it is not just in the workings of ideas about good and bad that institutions come to cohere. It is also due to the need for predictability of action by others; that is largely why the rules exist! In discussing the formation of equilibria in economic coordination, and the role of formal institutions in achieving these equilibria, Hall and 
Soskice (2001, p. 13) note the inadequacy of the formal institutional order per se as sole determinant. They argue that shared understandings about what other actors are likely to do are rooted in a sense of what is appropriate to do in specific circumstances. There is clearly a large research agenda definable to identify which norms, beliefs, or values come into play and when, but that is beyond the scope of this paper.

The same idea informs the analysis by Greif (2006, p. 22) of how 'the integration of cultural elements into a society's institutions is a mechanism that leads to their persistence'. He demonstrates from mediaeval history the divergent tracks taken in Western Europe and the Islamic Mediterranean, and suggests that institutions are more properly seen as systems, the components of which are beliefs, norms and rules (which sometimes manifest themselves as organizations), with all elements interacting and stabilizing into equilibria (subject to historical context). In this paper, I further consider the interaction between the beliefs and norms on the one hand and the rules and organizations on the other, seeing the two sets as fundamentally different in nature.

A final consideration is the closeness of match between the institutional fabric that a contemporary state might impose on a society and the core cultural axioms in the traditional culture. It might be a close match or a serious mismatch. One will give way to the other as they interact. The rise of the private sector in China, from being illegal in 1980 to contributing 67 percent of manufacturing value added in 2004 (OECD, 2005), is surely a manifestation of the upwelling of deep instincts and ideals about the running of both business and society, ahead of the amendments to formal institutions. In China still, the interpretation of what the 'good society' means leaves much experimentation necessary in the linking of culture and institutions.

In a later section, I will illustrate the institutional furnishing of China's semantic spaces and so make clearer the link between the domains of culture and action. It is tempting to pursue the metaphor and suggest that, since 1980 in China, a pile of old furniture has been slowly - but not completely - removed from a large building, itself undergoing major renovation and adjustment to its internal spaces, and that new furniture has been pouring into the building to furnish the spaces. Some of it has been thrown out again later, but many items have become stable fixtures in an increasingly hospitable and elegant ambience - at least for many people if not yet all.

\section{The Role of 'Social Axioms'}

Stable societies will have a culture in the form of a set of meanings for making sense of a particular societal universe. This collection of meanings is likely to be anchored in a meta-tradition of core features, traceable to the society's most fundamental ideals and myths. The main dimensions (although not the scores on them) of such 
meta-traditions, at the deepest level may well be universal across the range of human societies, since all face similar dilemmas in struggling to bring order to social life. The recent contributions by Bond et al. (2004) and Leung and Bond (2004) allow us a first glimpse of this set, derived empirically, and seen in their societal interpretations. Their term for the construct is 'social axioms' and their research aim has been to identify a pan-cultural structure of broad context-free beliefs likely to underlie behaviour. These beliefs allow a person to learn how to function in the world by representing how key aspects of society connect together: examples might be 'excessive power corrupts', 'aggression will lead to retaliation', 'your life is controlled by the spirits'.

These beliefs would help to anticipate, guide and rationalize behaviour, and would serve to explain outcomes. In spelling out relationships between things, they go beyond the influence of norms and values to provide a framework for guiding action, not just on the grounds of what should be but on the grounds of what is. This combination brings to mind Berger's discussion of the 'process of legitimation' (Berger, 1967, p. 29) with its mixture of description and prescription providing answers to the question 'why?' and contributing crucial support to 'the swaying edifice of social order'. In moving beyond values per se this is a significant new empirical version of culture. Tested across 40 countries and with 9,928 subjects, five primary variables were strongly endorsed as universals. With each as a continuum, they are:

1. Social cynicism. A negative view of human nature as easily corrupted by power and justifying mistrust; a fundamental requirement in contexts where deception by others is frequent and gullibility might lead to exploitation and oppression.

2. Social complexity. The acceptance of inconsistency, multiple options, paradox and the absence of rigid rules.

3. Reward for application. Effort, knowledge, planning, will lead to positive results or at least guard against negative ones.

4. Spirituality/religiosity. Acceptance of supernatural forces and the benefits of religious belief and institutions for societal order and harmony.

5. Fate control. Life's events are pre-determined, and there are some ways in which people can influence these events (i.e., with the contradiction included).

It is unnecessary to dwell upon the details of the findings, which are separately available, except to make two observations: first, the variation between societies in the salience of religion is noteworthy; second the social cynicism results echo strongly the concerns with the workings of trust that have so occupied theorists. These five social axioms allow us to go beyond values into prescriptions for action. As principles of behaviour that apply throughout the society, they shape 
responses into acceptable forms and thus act to integrate what is going on across the total.

As this process of constant partitioning of reality continues and as the loose coupling of the differentiated and specialized meanings manifest in the institutions moves the society towards diffraction, it can only be held together if a countervailing framework exists to provide a tightly coupled, integrating overlay. This is one of the key roles of culture, and this is why it is distinct from 'institutions'. The institutional proliferation permits and encourages plurality; the culture, by providing the shared meanings within and across the semantic spaces, holds the whole thing together. As was noted by Coser in an introduction to the work of Durkheim,

... although the collective consciousness in the world of modernity can no longer define the specific norms that pertain to the exercise of differentiated tasks, it is still needed so as to assure overall coordination and integration of the society as a whole. (Coser, 1984, p. xviii)

The distinction made earlier between institutions with members and tangible features, and culture as meaning partitioned into semantic spaces, is relevant here. The absence of fixed membership and rules in the semantic spaces allows them to foster constant re-affirmation and re-interpretation by the members of society moving in and out of them and - significantly - carrying meaning between them. The social axioms are the ground base for the construction of that shared perceived reality.

The images used to convey the idea of the tight coupling provided by the culture across the action spaces are commonly drawn from the brain. Hofstede's (1980, 1991) ideas of the 'collective programming of the mind' or the 'software of the mind' are matched by Sorge's (2005, p. 52) view that 'action systems are the neuronal circuitry that makes effects reverberate throughout society'. He adds more graphically the idea of a 'network of communicating tubes' to convey the way the meanings are spread across the society to achieve consistency and integration. This, for him, is the societal effect; in other words, the meanings become connected, and 'tightly coupled action systems ensure that institutional and cultural adaptation and evolution are cross-referenced across institutional domains' (Sorge, 2005 , p. 52). One might call these wider meanings shared expectations that have social force.

A large question arises about the alignment of: (i) the wider societal axioms; with (ii) the more specific meanings inside the semantic spaces; and (iii) the institutional scaffolding that shapes action. It would require another paper to deal with such an issue, but suffice it to say here in simple terms that the institutions may usefully be thought of as the linking mechanisms. The argument for this view was distilled from Weber by Schluchter in the following terms. In a sentence normally regarded as a key to his work, Weber wrote, 
Interests (material and ideal) not ideas directly determine man's action. But the world views, which were created by ideas, have very often acted as the switches that channelled the dynamics of the interests. (Weber, 1930, p. 280), cited in (Schluchter, 1981, p. 25)

The world of ideas and symbolic systems of meaning informs us 'for what and from what we want to and can be saved' (Schluchter, 1981, p. 26), but this is not enough to channel the dynamics of the interests. For that it is necessary for people to know the means whereby the material and ideal goods desired can be attained. Hence the institutions that represent those means come to mediate between the ideas and the interests, and 'only through institutionalization do material and spiritual wants receive a socially relevant solution' (Schluchter, 1981, p. 27).

Cultures do not always display the kind of cohesiveness implied in much research. In an attack on this assumption, Archer (1996, p. 4) called it the Myth of Cultural Integration, seeing it as 'one of the most deep-scated fallacies in social science ... the ... assumption of a high degree of consistency in the interpretations produced by societal units'. She pointed to two areas of potential inconsistency: internal discontinuities and conflicts within the set of ideals; and the absence of social uniformity in expressing the ideals through action. Such caveats are especially relevant for China in the present period.

In summary, I have argued, first, that culture is a set of meanings derived from peoples' attempts to make sense of their surroundings. Second, those meanings gather in clusters within semantic spaces, each of which derives from the fact that people come together to do things and they do things across a vast and complex array of activities, sharing and affirming the relevant meanings associated with these activity domains as they do so.

Third, inside each semantic space, a shifting population of actors comes and goes, as if it were a room in which something specific happens, but while they are in there, they share the meanings accumulated within it. They instantiate this social reality by conforming to the rules and norms within the space. For instance, they come together to eat, and they know what to do with whom, when and what to expect, even though they do not spend their whole time dealing with food.

Fourth, if those rules within each space shape behaviour so strongly that conformity and predictability are high, then the social conduct becomes institutionalized and the meanings are acted out in daily life. So, in the semantic space for eating, there are standard recipes commonly found and standard table shapes, cutlery, table manners, roles etc. Fifth, those institutions have members who perpetuate and adjust them. As institutions, they are tangible and visible conventions for the achieving of order, standards and compliance. In the catering industry for instance, restaurant owners and guilds of chefs maintain consistency, visible in codified form as menus and recipes and ratings. Food markets provide what is wanted in an organized response to balancing supply and demand. Pcople cooking 
at home for their families work within the limits of what is expected and available to the family institution.

Sixth, the meanings within the space (i.e., the culture) are not tangible in the same sense as are the institutions. These meanings are beliefs about how the world works and, in particular, about that bit of the world to which the space is devoted. Ideas that are common across the wider society come in. Food traditions about what is good to eat, beliefs about health maintenance, sociability, sharing, hospitality and status are all manifest in the action space of eating, and they underpin the more specific norms. Such deeper beliefs belong to everyone and no one. They have accumulated over time like sediment. Prior to being channelled via the institutions and acted out, these interpretations of reality (whether they derive from a semantic space or from the wider society) have a highly significant function in their own right - that of providing a useable and shared definition of the surrounding world that people must negotiate together.

Seventh, if the beliefs and norms belong to everyone and no one, the institutions belong to someone. Institutions cannot exist without some person taking responsibility for their maintenance. Once a rule comes into existence it becomes necessary to enforce it. Once a structure for regularizing action is created, it needs members to enact the purposes served by that institution and to support the rules believed necessary to achieve those purposes. The furniture in the rooms is designed, brought in, used, put in a different position, redesigned, taken out and replaced by people who come in and out of that space to use it.

I now turn specifically to that last distinction and so to outline the argument for the separate treatment of culture and institutions, using China's private business sector as the example. As earlier noted, this part of the account remains indebted to the ideas of Sorge on the societal effect and to the interpretive school of scholars such as Luhmann, Berger and Luckmann, Giddens and Geertz.

\section{How Chinese Societal Culture Works}

In a wider sense than the purely economic, China is changing substantially. As Guthrie (2006, pp. 235-255) has described it: the workings of the National People's Congress display a progressive separating of powers in the political hierarchy; the legal system is now encouraging citizens to claim their rights; grassroots participation in elections is now extensive; labour contracts now permit an escape by workers from dependence on employers and this has led - significantly for this paper's agenda - to a change in the meaning of work; a bourgeoisie is growing as the Chinese Communist Party permits the membership of business owners; party dogma is giving way to performance in societal improvement as a basis for legitimate power; the market drives much policy making. These features all require the shaping of new institutions, each innovation having to fit into a previously 
established matrix of meaning. In this transition, what Droege and Johnson (2007) term 'meso-institutions' emerge as intermediate forms.

In the development of Western Europe and the USA, over centuries, as the societies and their economies became more complex, institutions were formed to take the strain of providing order and facilitating exchange. They were based on core cultural beliefs in possessive individualism (Macpherson, 1962), corporatism, and self-governance (Greif, 2006, p. 398), and they contributed to prosperity in at least four ways: they fostered the division of labour; they sponsored property rights; they created bodies, i.e., corporations, to enable risk taking, initiative and technological innovation; and they fostered adaptability in the coordination of economic action.

China has followed its own track, and the example of Western economic history is of limited value, except for its ability to remind us of the universal qualities of efficiency, innovation and adaptiveness to be achieved by any system. What is to be achieved is definable. How it is to be achieved, given the starting conditions, is open to trial and error, borrowing, hybridizing, inventing and,perhaps - as in cases such as tax farming in China - reinventing and transforming tradition.

At the level of large-scale organizations, a particular challenge occurs, that of vertical communication in firms now being challenged to perform in innovation and adaptation but lacking the managerial response patterns to do so at world standards of competitiveness (Gilboy, 2004; Lieberthal \& Lieberthal, 2003; Nolan, 2004). In an open society, the invention of new structures proceeds via experimentation; that, in turn, is fostered in conditions where variety is permitted, encouraged, or required by the external forces of competition. The contrary imposition of mechanical solidarity by a commanding centre manifestly fails to provide for adaptation or operating efficiency; the evidence from the Soviet and Maoist experiments, and from totalitarian states more generally, supports that conclusion overwhelmingly. A common denominator in societies that evolve successfully (in terms of widely accepted quality of life criteria) is pluralism (Rawls, 1999, p. 564). In these circumstances institutional entities become increasingly specialized, proliferate alongside each other, but become more loosely coupled in line with their increasing autonomy. They do, however, still coexist and behave interdependently. Peaceful cooperation between them occurs across the niches where they come together as people accept the rule of enforced law in the interests of order and social stability.

Semantic fields can be seen as primary and secondary. Following Friedland and Alford (1991), I illustrate the primary semantic fields in Figure 1 as comprising: family, religio-social philosophy, person-society relations, the economy and the state. Each of these domains is full of meaning and the meaning derives from the combination of: (i) an inner core of deep meta-traditions, such as 'the five relationships' or 'the ten commandments', individualism or collectivism and their associated interpersonal logic and mandates; plus (ii) the social axioms that reflect accumulated learning and coping, appropriate to the values. 


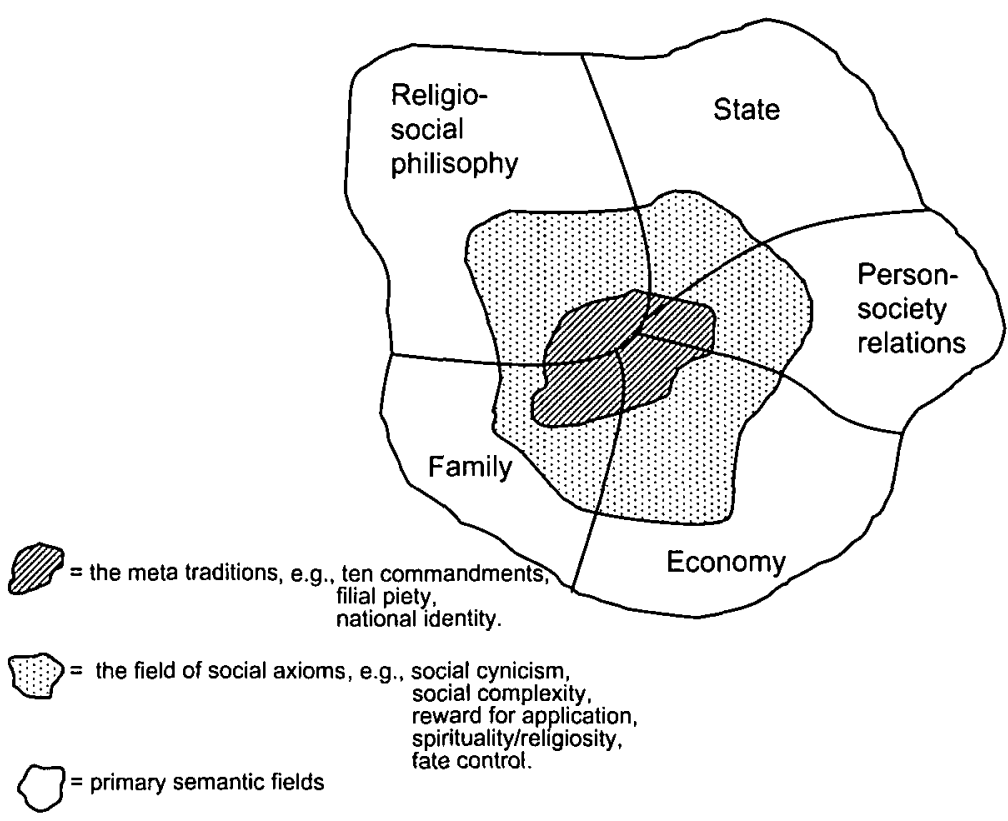

Figurc 1. Primary semantic fields, social axioms and meta-traditions

Note: The five core divisions of the societal space are derived from Friedland and Alford (1991). The social axioms are reported by Leung and Bond (2004).

The secondary level, reflecting the diffraction of social action into more specialized semantic spaces, is illustrated in Figure 2. In this representation, the primary meanings feed into the secondary semantic spaces and are refined, added to and made more specific, creating new meaning spaces. Each of these spaces has its own vocabulary and its own norms. They are illustrated here by taking the semantic spaces entailed in the owning and managing of a small or medium size enterprise in the private sector of China. The categories for these semantic spaces derive from formal interviews about executive rationale conducted with 30 senior Chinese executives from the SME sector (Redding \& Witt, 2007) plus informal discussions on the same topic held with approximately 350 more between 2002 and 2006. The categories are the following.

1. Connections and reputation building: the actions associated with stabilizing uncertainty in an information-poor environment, where trust is personally based and limited to one's established network.

2. Secrecy: the work of maintaining control over crucial financial and technical information in a context of mistrust of formal institutions and where the retention of discretion to decide and commit resources is strategic.

3. Managing employees: the actions associated with employment, incentives, control of work and welfare. 


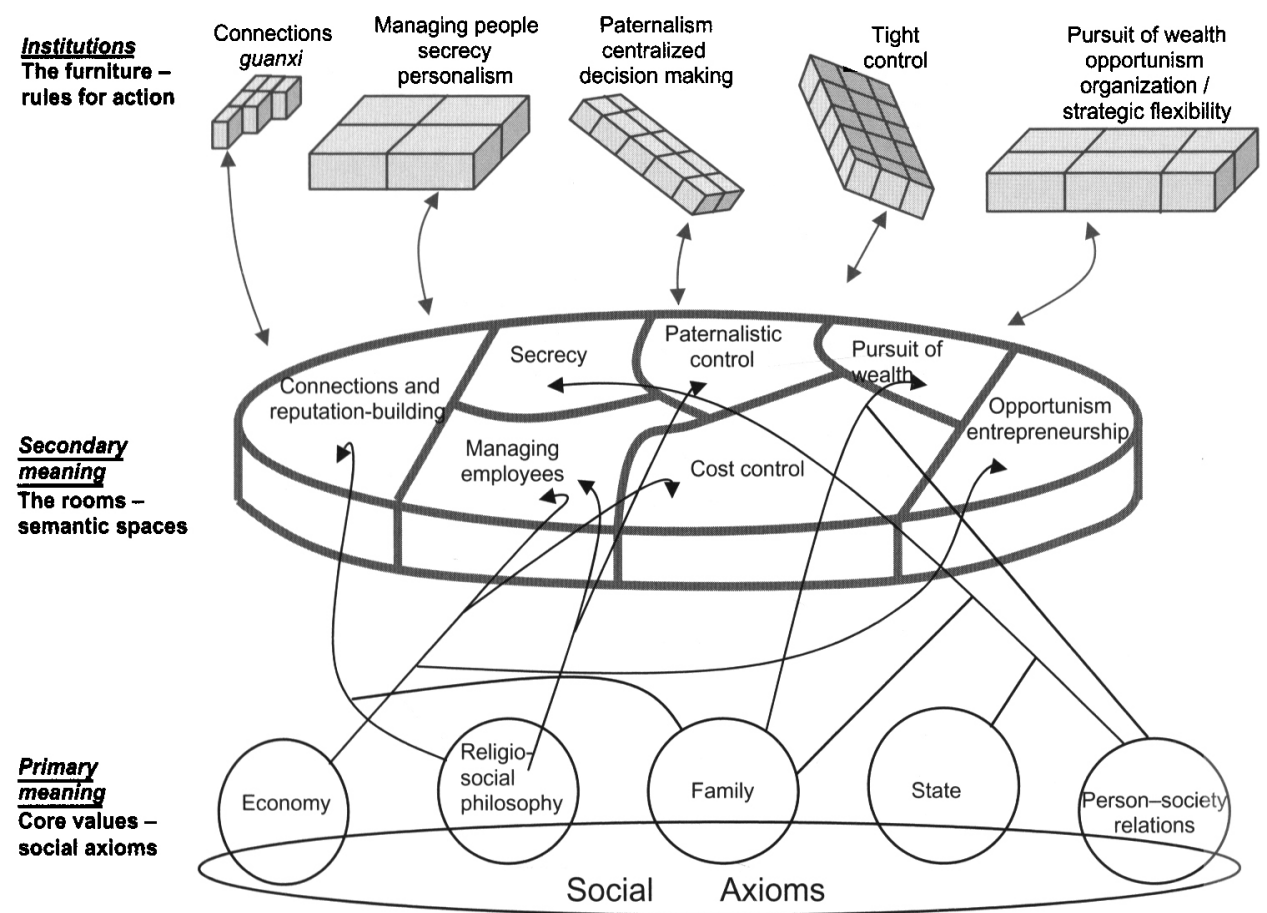

Figure 2. Semantic spaces and their relation to social axioms and institutions in the context of small and medium enterprises in China

Note: Causal arrows are illustrative only.

4. Paternalistic control: the work of being a leader in conditions where authority is legitimized by acts of paternalism and where centralized decision-making is normal and legitimized.

5. Cost control: actions associated with cost efficiency.

6. Opportunism and entrepreneurship: the managing of strategic initiatives, in pursuit of organizational growth.

7. The pursuit of wealth: becoming rich to achieve security and status in conditions of uncertainty.

In each of these semantic spaces the culture is visible in a widely shared set of meanings. At its most fundamental, it amounts to a set of commonly adopted ends and means. As Weber (1922) specified long ago, the web of meanings in which action is suspended may be seen as value rationality (ends) and instrumental rationality (means). Because of this, the resolution of who gets what in a society tends to be shaped by ultimate values. The Japanese moral sense of responsibility for dependent employees affects behaviour by heads of organizations and engenders a priority on keeping people employed, rather than paying dividends to relatively unknown shareholders. The US sense of competitive striving and individual responsibility 
justify few such scruples and the system's societally legitimate performance rationality assigns priority to share owners. So, in Japan, the richest 10 percent of the population earns 4.5 -fold the income of the poorest whereas in the USA the equivalent figure is 15.9-fold. China now exceeds the USA in its sponsoring of a new rich class with a figure of 21.6-fold (UNDP, 2008). The new rich of China, owning their own enterprises, could not have achieved the proportion of societal wealth they now have until the society's ends and means shifted; it needed Deng Xiaoping to say that it was glorious to be rich, that socialism was not poverty, for the ideological move from communal sharing and equality under state ownership to individual property rights and market competition.

In each semantic space identified here for the owner-manager, a set of core ideals and received wisdom (derived from the social axioms and experience) will shape the ends being pursued, even though unconsciously. Having a good network, a respectable reputation, control over resources, a capacity for risk, discretion to decide and a workforce you can rely on sets you up to survive in a highly competitive business arena. Building an enterprise also achieves other ends: status, family security, contribution to societal progress, etc. This complex pattern of interlocking ends and means is the business culture characterizing the semantic space of the Chinese private sector. It is also a living object, constantly shifting shape, as new possibilities demand new norms and rules, and old ideas fade from significance, like the Communist dream.

It is important here to consider the nature of the 'means' under discussion. What is entailed is that certain methods of approach are seen as legitimate. It is, for example, legitimate in this Chinese business culture to build ties of obligation based in reciprocity. That is a norm. It is not a behaviour pattern, although it becomes one when acted out in the institution of guanxi (connections).

The workings of institutions are at the top of Figure 2 and are drawn to suggest a more formal, i.e., regularized and predictable, structure than exists in the worlds of meaning that evolve in the semantic spaces. As they are the commonly adopted norms of action, they may well become codified. That codification might be informal, as in the common understandings about reliability, status, respect, sanctions, etc. that run though guanxi networks. They might equally be formal, as when a source of lending such as a bank is concerned to intervene in the cost control space and imposes standard reporting requirements, called rules. Or they may be a mixture, as when a boss, working in the paternalistic control space, telephones all key executives daily for a report; that is also an institutional procedure.

Tables $1-3$ show the three categories in which I have presented the workings of culture in the case of China's private sector as a whole, allowing also for the changes now running through it. They are referenced to indicate the supporting research literature. At its centre (Table 2) are the semantic spaces that together contain the universe of meaning for the typical owner-manager; those meanings being connected across the society and bringing most organizational behaviour 
Table I. Studies related to social axioms in the context of the Chinese private sector

\section{Economy}

Competition for scarce resources: Foster (1967).

Opportunism and deal-making: $\mathrm{Li}(2005)$.

Network capitalism: Hendrischke (2007).

Local corporatism: Sung (2005).

Religion

Confucian-based order and roles: Hamilton (1990).

Taoist accommodation with nature: Tang and Ward (2003).

Harmony: State Council (2005); Rappai (2006).

Reciprocity: Ralston, Pounder, Lo, Wong, Egri, and Stauffer (2006).

Hierarchy: Kong (2006); Cheng, Chou, and Farh (2006).

Family

Family as prime focus of collectivism: Li (2005); Chen and Chen (2004); Guthric (2006).

Pursuit of security in ever-hostile world: Kong (2006).

Paternalism: Hamilton (1990).

Local identity: Goodman (2007).

Sclf-interest: Kong (2006); Ralston et al. (2006).

Statc

Strong state and now strong provinces: Ralston et al. (2006).

Mistrust of formal institutions: Li (2005); Wederman (2004); Ding (2000a).

Decentralization: Guthrie (2006).

Diminishing welfare role: Guthrie (2006).

Person-society relations

Reciprocity as moral issue: Batjargal (2005); Luo (2005).

Control your own and family fatc: Guthrie (2006); Kong (2006).

Dependence: Chen (2006); Li (2005); Ralston et al. (2006).

Grass roots participation in politics: Guthrie (2006).

Limited trust: Studwell (2002); Chen and Chen (2004); Kong (2006).

Role conduct: Hamilton (1990); Kong (2006).

Increasing rationality: Guthrie (2006); Lu and Alon (2003).

inside reasonably predictable boundaries, as the meanings are shared and evolve together with changes to the society.

At the base are the social axioms (Table 1), the deeper layers of societal beliefs about how the world is and scripts and values about how to behave in it. These are the fields of primary socialization that produce what might be termed 'Chinese' behaviour. Here these are treated only insofar as they relate to the economy. Their influence is seen as underlying the sets of meanings that emerge during secondary socialization, as specialized understandings accrete within the semantic spaces. With these two layers, we are not yet at the level of institutions, i.e., people following stable patterns of action. We are instead at the level of culture - the giving of meaning via shared understandings of ends and means. These are the rooms full of meaning but empty of people. Then the people come in, populate the space, adopt the meanings (or negotiate their adjustment) and start behaving according to 
Table 2. Studies related to semantic spaces in the context of the Chinese private sector

Connections and reputation building

Build a personal trust network: Li (2005); Batjargal (2005).

Use connections for kcy resources, e.g., information, political support, funding: Li (2005); Ding (2000a); Hendrischke (2007); Kong (2006); Batjargal and Liu (2004).

Family reputation via socictal service and/or wealth: Dickson (2003).

Do not trust strangers: Chen and Chen (2004); Kong (2006).

Managing employces

Patcrnalism: Kong (2006).

Discipline and control: Kong (2006); Feng and McDonough (2006).

Didacticism: Huang et al. (2005); Lu, Leung, and Koch (2006).

Hicrarchy: Casimir and Li (2005).

Work ethic: Ralston et al. (2006).

Meaning of work changing from welfare context to rationality: Tsui, Wang, and Zhang (2002); Guthric (2006); Kong (2006); Ralston ct al. (2006).

Work practices changing also: Chow (2004).

Cost control

Frugality: Redding (1990).

Money must be made to work: L.i (2005).

It is my own money at stake: Studwell (2002).

Control in detail: Kong (2006).

Opportunism and entrcprencurship

Constant search for opportunity spaces: Li (2005); Ding (2000a); Jia, Zhang, Qian, Cui, and Chen (2006).

Scarch for a successful formula: Tam (2001).

Hedging of risk: Hendrischke (2007).

Constant lcarning: Tenev (2006).

Rising materialism: Rosen (2004).

Manage professionally: Dolles (2003).

Secrecy

Kecp your finances and technology to yourself and trusted others: Studwell (2002).

Do not trust formal institutions: Studwcll (2002).

Information is a strategic tool: Boisot (1995).

Patcrnalistic control

Owner dominance in control decisions and representation: Hendrischke (2007); Feng and McDonough (2006).

Welfarc exchanged for loyalty: Hamilton (1990).

Pursuit of wealth

Wealth necded against surrounding insecurity: Kong (2006).

High savings and risk hedging: OECD (2005).

Reliance on property: OECD (2005).

Wealth as source of status: Farrell, Gersch, and Stcvenson (2006).

them in learned, predictable and acceptable patterns. Thus institutions then fill the meaning spaces like furniture. They are given in Table 3.

As noted earlier, the institutions work in a different way than do the semantic spaces.

To summarize, institutions have members, and those members interpret the semantic space meanings and enact them by converting them into stable patterns 
Table 3. Studies related to institutions in the context of the Chinese private sector

Connections

Ties of exchange and reciprocity in network capitalism: Zhang and Reinmoeller (2007);

Hendrischke (2007); Batjargal (2005).

Funding support between friends: Hendrischke (2007); Tsai (2002); Allen, Qian, and Qian (2004).

Business partnerships: Wederman (2004); Child and Rodrigues (2005).

Associations: family, clan, region, sector: Chen and Chen (2004); Batjargal (2005); Sung (2005).

Information cxchange: Hendrischke (2007).

Family ties: Redding and Witt (2007); Dickson (2003).

Government ties: Li (2005); Ding (2000a); Diamant, Lubman, and O'Brien (2005); Gold, Guthrie, and Wank (2002); Sato (2003).

Local corporatism: Feuchtwang (2004).

Managing employecs

Top-down communications: Feng and McDonough (2006); Cheng et al. (2006).

Low manager-worker interdependence in work matters: Yu and Egri (2005); Zhu (2005);

Bachrach, Wang, Bendoly, and Yang (2007).

Taylorism: Zhu (2005).

New, more rational patterns emerging: Nee and Cao (2005); Kong (2006); Ding and Warner (2001).

Cost control

Funding from savings: OECD (2005).

Tight control of expenses and working capital: Li (2005).

Opportunism

Flexible organizations: Krug and Kuilman (2007).

Opportunistic diversification: Jia et al. (2006).

Informal and collaborative lending: Ding (2000a).

Information arbitrage: Ding (2000a).

Legal structures conducive to entrepreneurs: Guthric (2006).

Mobile labour markets: Guthrie (2006).

Secrecy

Very limited disclosure of performance data and industry data weak: Allen et al. (2004).

Opaque ownership structures and connections: Kong (2006); Ong (2006); Mcycr and Lu (2005); Ding (2000b).

Political co-optation often invisible: Ding (2000a,b); Gold et al. (2002).

Rapid evolution of more rational institutions: Zhang and Rcinmoeller (2007); Guthric (2006); Lo and Tian (2005).

Paternalism

Growing bourgeoisie of owners: Tenev (2006).

Transfer of welfare responsibility from the state to firms: $\mathrm{Li}(2005)$.

Re-emergence of many traditional values: Inglehart and Welzel (2005).

Continuing workforce dependence: Zhang and Reinmoeller (2007).

Continuing vertical patronage in the society: Huang (2004).

Pursuit of wealth

Very high savings rate: OECD (2005).

Conspicuous consumption and display: Farrell et al. (2006).

Property investment: OECD (2005).

High social and geographical mobility: Guthric (2006).

Self-development via education: OECD (2005).

Growing middle class: Guthric (2006). 
of behaviour. Those members interact with the meanings in the semantic spaces and affect the evolution of those meanings. The behaviour of those members in 'instititionalizing' the meanings helps to keep active the 'neuronal circuitry' throughout the society, with which the culture in the semantic spaces remains tuned to that society and consistent across it.

But the meanings in the semantic spaces remain ontologically distinct as a category, for two reasons. First, meaning is not action. Second, its existence as societal gluc, holding together a vast, varied and proliferating set of behaviours, requires that it be independent of regularization if it is to function and if the society is to continue to reflect its own core ideas and ideals as it evolves. Such independence does not imply separation as the two fields of meaning and action are reciprocal, but it does mean that their different workings give them different ways of fitting into the wider analysis. As Geertz (1973, p. 5) has observed,

Believing, with Max Weber, that man is an animal suspended in webs of significance he himself has spun, I take culture to be those webs, and the analysis of it to be therefore not an experimental science in search of law but an interpretive one in search of meaning.

Space constraints do not permit a detailed discussion of all the components of this diagram, as that would need to be book length. But a number of summary points may be useful, before finally considering the implications for wider theory.

Social axioms in China. At the level of the deeper culture and social axioms, the five main fields identified here as convenient envelopes contain the society's most fundamental meanings guiding life. Analysis of their contents will indicate variation between societies not just in specifics, but also in the overall salience of each dimension, so that a society such as China with a strong state will see much influence stemming from that component; in China one might also expect that the cultivation of relationships as a prime source of social order would add salience to the dimension of person-society relations. The axioms will reflect the social history of China and its evolution as a Confucian-based patrimonial bureaucracy, the fundamental design principles of which were: (i) reliance on families as the selfgoverning core social units; (ii) use of an apparatus of professional administrators to handle a decentralized, but still controlled form of government; (iii) ultimate dependence on personalized central authority; (iv) personal relations as the guaranty of trust; and ( $v$ ) ideals of benevolent humanism balanced by discipline, order and hicrarchy. The past 50 years have seen a number of massive assaults on these ideals. The first set of these came from the social experiments of the Mao era, still visible in the retention of Party control. The second set is now resulting from the economic successes of more recent decades and the arrival of wealth, consumption and new forms of communication. The growth of the economy is also serving to 
legitimate the extensive de-centralization of economic decision-making. China is also now deeply penetrated by external ideas that no amount of web censorship can rein in.

As a result of these historically new forces, the old culture is adjusting, and it is not clear at present how it will eventually stabilize. Recent data, however, point to two relevant features. Inglehart and Welzel (2005, p. 112) report, after four waves of the World Values Survey, that there is an unusual degree of agreement between generations in China on core values, thus suggesting the retention of core ideals. The traditional secularism of China, supported by the this-worldly humanism of the Confucian ideal, appears to be re-affirmed in the unusually low figure - in fact the most extreme in the world - for religious beliefs and participation (Norris \& Inglehart, 2004, p. 226). In the background also is the ideological vacuum left by the demise of the Communist ideal and the absence, so far, of a replacement other than the obvious contender, nationalism.

To fill that vacuum, China appears to be returning to its cultural roots - family, personalistic trust, hierarchy, government derived order - but at the same time to be attempting to add the new components of rationality, professionalism and local participation, to that old mixture. Previous moves in this same general direction by Hong Kong, Singapore and Taiwan have produced radically contrasting alternatives for success (and have done so on a much smaller scale). That variety suggests that China will produce yet another formula from the experimentation going on in its laboratory. It is not yet visible, even in outline, nor is it clear that it will be describable as a single system.

I now turn to the fields of secondary socialization, in which the culture becomes much more specific - and focused inside semantic spaces.

Meaning in the semantic spaces of private business. To run your own company in China means that you have to behave in ways that: (i) pay attention to certain crucial features related to being competitive and efficient; and (ii) fit what you do to the surrounding context of what is expected of you by employees, suppliers, customers, bankers, officials, co-owners, etc. These requirements sponsor behaviour within the seven semantic spaces identified, each with its own readings of reality. It is possible to see running through these spaces the core themes of paternalism, personalized trust, control, ambition for wealth and opportunism.

We are still here at the level of meaning, perhaps best grasped by imagining what a manager would say if you asked him or her: 'How do you make sense of building connections and reputation?' In other words, how people explain to themselves why they do things the way they do them. They are usually, of course, doing things without calling up such reasoning from their subconscious but, if asked, could arguably produce coherent explanations.

To make connections is to acknowledge that the surrounding society is not easy to deal with without friends to help. You cannot trust strangers and officialdom 
does not always behave predictably or 'fairly'. Your capacity to influence others in such networks rests largely on your reputation for reliability and on your perceived respectability. It is this latter factor, combined with wealth, that will bring honour to your family.

Employees are subordinates who will both work hard and expect discipline, but those on whom you depend will need to be treated as dependents for whom you are partially responsible. When your own money is at stake, great care must be taken that it works hard and that it is not wasted. In moving the firm forward, you must learn constantly about the industry and search constantly for opportunities. The ideal is the formula you might create to make money by combining things in new ways, before someone else innovates in this way. But you are not restricted to one field of business and should hedge risk. Trust only those you know well and do not give information away. You and your owning partners have the right to decide all issues, to commit resources and you speak for the whole enterprise with outsiders. There is always surrounding uncertainty and things can change quickly, so you must fulfil your family duty to accumulate wealth and place it somewhere safe.

Institutions: the making of stable behaviour patterns. When meanings are widely shared, the actions they then make 'meaningful' become predictable and stable, so that people: (i) can know how to enact the shared understandings; and (ii) can predict the behaviour of others. By this process, the 'institutionalizing' of the meanings provides order. In doing so in semantic spaces of complexity, such as law or accounting, such order often becomes elaborated and codified and requires much learning by members, of both rules and roles. In other less clearly bounded semantic spaces, such as networking or offering hospitality, order may simply be maintained by accumulated understanding and socialization. In most cases, these enactments need to be protected against deviance and misinterpretation, and there is a vested interest for many in having things predictable that justifies sanctions against those who do not conform. These might range from a dress code to a set of membership rules, or codes of practice. For most, conformity is a fair price to pay for the benefits of membership, as it leads to being able to take part in the action. Deviance can cost dearly if it means exclusion from a field of action.

In the semantic space of 'connections and reputation building' a wide set of institutions has been established to provide the scaffolding for network capitalism. Stable patterns of behaviour exist for blending reciprocity into exchange processes, including processes of funding, information exchange and business partnerships. Family, clan and regional networking provides much of this basic architecture. 'Managing employees' follows a pattern of response adopted so widely as to be a stable institutionalized pattern. Organizational power and decision-making is typically centralized and, apart from with key technical specialists, the average workerboss relationship is very hierarchical and not strongly interdependent. Workers are essentially extensions of the machine in most manufacturing, and Taylorism is 
normal, including a share of serious abuse in some cases. Variations in Confucian humanism from boss to boss do not radically alter the fundamental power and communication structures. 'Cost control' is conspicuous in most private sector Chinese enterprises and its good effects on efficiency are visible in performance data in the aggregate (e.g., OECD, 2005). Because of the institutionalizing of 'secrecy', however, it is extremely difficult to demonstrate this empirically. Within this latter space, the constructing of complex organizational webs is also well established and so too is the dividing of much action between those who know what is going on and those who can only guess. This institutionalized opacity has been an important component in the growth of many new complex business groups and in much opportunism in accessing state assets (Meyer \& Lu, 2005; Rosen, 2006). 'Opportunism' per se and its accompanying field 'the pursuit of wealth' contain a predicable pattern in behaviour given the following conditions: very rapid and sustained economic growth; the fast absorption of new technology usually entering from abroad; radical restructuring of the economy and of government policy consistently in the direction of encouraging entrepreneurship; a powerful drive to improve the acquisition of wealth; the growth of new structures and institutions in financing, training, distribution, access to foreign markets - all capable of assisting in the creative pursuit of opportunity. The vast proliferation of new firms, and within them of opportunistic diversification as they grow, are the main institutional vehicles carrying this momentum. 'Paternalism' lies at the centre of the set of Confucian-derived institutions, and surrounding it are related responses: 'iron rice-bowl' welfare structures now transferred from the state to business owners; high levels of discipline and punishment; a proliferation of such owners across society as the concern with control makes for so many small firm start-ups; and familism returning to solve the problems of mistrust of strangers and of obligation to this core social unit.

\section{GONGLUSION: IMPLICATION FOR FUTURE RESEARCH}

I have contended that culture provides meaning for institutions; that it may be seen at two levels related to primary and secondary socialization; that it belongs to cveryone and no one; that it adjusts to its surroundings; and that it serves to hold together a commonly proliferating set of institutions as a society progresses towards greater complexity. I also contend that it may best be seen as existing inside envelopes wrapping semantic spaces in which specific forms of action occur. Its connection with action, and then with institutionalized action, may thus be analysed so as to make clear how the components variously function and fit together.

In order to use such an approach, it is necessary to begin with an idea of the semantic spaces of interest and ideally to derive those empirically from the minds of local respondents (for examples in the business world see e.g., Guillen, 1994; Guthrie, 1999; Kotter, 1982; Mintzberg, 1973; Redding, 1990; Witt, 2006; and a 
wider literature in ethnography). How local actors make sense of the world begins with a set of categories into which their constructions fit, and they are not necessarily those used by theorists, or by people from other cultures. It is, however, reasonable to suppose that where action is clearly definable, as, for example, would be broadly the case for managing a workforce or relating to key customers, then a semantic space could be assumed.

If firms are expressions of social order, i.e., 'are imbued with the patterns of meaning of the larger society in which they find themselves' (Biggart \& Guillen, 1999, p. 726), then distinct interpretive schema are in play. Two main consequences follow: best practices are likely to be locally embedded; and distinct competitive capabilities become significantly, if not entirely, local also and form the basis of societal strategic advantage. The economic implications of this are clearly substantial as are also the ramifications for policy-making at a number of levels. Not understanding such issues can be argued to be the basis for much misdirected cross-societal expenditure and effort.

Slightly amending DiMaggio and Zukin (1990) by dividing their third category, it is possible to see the study of these interpretive schemas as boiling down to four research questions.

1. How do actors define their interests?

2. How does a society constrain the individuals pursuing those interests selfishly?

3. How do people coordinate to mobilize their capacity for cooperation?

4. To what ends do people use these particular coordinative means?

These questions constitute a research agenda for scholars willing to work across disciplines, to collect data more ethnographically and with a respect for alternative meaning structures. Two extra features then arise to inject further complexity into what might have been a tidy set of questions. The trade-offs that are apparent between questions (1) and (4) bring into the account the likelihood of people using two parallel frames for action, namely those based on individual sentiments and those that are 'other-regarding' (Etzioni, 1988). This means that the capacity of people to operate with mixed motives and to live with the paradoxes entailed, becomes part of the research agenda. The second complication is that each semantic space may contain its own rationale shared among its temporary inhabitants and that the work of social axioms in knitting together a societal culture may not lead to complete conformity. The logics of action may well be better explained within the spaces and so more fine-grained studies may be justified.

In their theory of systems of exchange, Biggart and Delbridge (2004) proposed a typology that permits further exploration of differences in market structures and in forms of coordination and control. Their agenda was to turn research away from debates about what really constitutes a market or what is the 'true' nature of rationality and to ask instead about the conditions in which certain assumptions 
hold. That contribution, as also that of business systems theory more broadly, is of major value in fostering the comparison of how economies work. It provides stimulus to new propositions and insights about the connections between the social and economic worlds. But, as they acknowledge, the development of classifications into types does not solve the problem of explaining the conditions under which any one type might have been formed and might now evolve. For these issues to be understood requires the building of connections between societally specific meanings, institutions and economic behaviour. That, in turn, requires a disaggregating of the component parts, arguably the most problematic of which are culture and institutions. It is essential then to begin by saying where each of these begins and ends.

\section{NOTE}

The core idea of 'semantic spaces' in this paper originated with the work of Arndt Sorge, whose own term is 'action systems' - inspired by Niklas Luhmann's idea of social spaces containing specific meanings. Max Boisot usefully pointed out the significance of semantics in this metaphor and the notion of such spaces as fields. Of importance also have been the idea of 'social axioms' initiated by Kwok Leung and Michael Bond and the much appreciated specific suggestions provided by Michacl Bond. Valuable conversations with John Child, Peter Berger, Wang Zhong Ming, Subramanian Rangan, Barbara Krug and Philippe d'Iribarne are also gratefully acknowledged, as is also the encouragement of Anne Tsui and the IACMR. Crucial also have been the several hundred conversations with Chinese executives, mostly owncr-managers, over recent years in China. The support of INSEAD's Euro-Asia and Comparative Rescarch Centre, the Lce Foundation of Singapore and the INSEAD/Wharton Alliance, arc also noted with much gratitude. The Bjorkliden conference of the Institute of International Busincss of the Stockholm School of Economics provided much valuable stimulus. The technical contribution of Nathalic Gonord is gratefully acknowledged.

\section{REFERENGES}

Allen, F., Qian, J., \& Qian, M. 2004. Laze, finance, and economic grozeth in China. Wharton school working papers, University of Pennsylvania, Philadelphia.

Archer, M. 1996. Culture and agency: The place of culture in social theory. Cambridge: Cambridge University Press.

Bachrach, D. G., Wang, H., Bendoly, E., \& Yang, S. 2007. Importance of organizational citizenship behaviour for overall performance cvaluation: Comparing the rolc of task interdependence in China and the USA. Management and Organization Revieze, 3: 255-276.

Barrctt, G. V., \& Bass, B. M. 1976. Cross-cultural issues in industrial and organizational psychology. In M. D. Dunnette (Ed), Handbook of industrial and organizational psychology: 1639-1686. Chicago, IL: Rand-McNally.

Batjargal, B. 2005. Comparative social capital. William Davidson Institute Working Papcrs, University of Michigan, Ann Arbor.

Batjargal, B., \& Liu, M. 2004. Entrepreneurs' access to private equity in China: The role of social capital. Organization Science, 15: 159-172.

Becker, J. 1996. Hungry ghosts: China's secret famine. London: John Murray.

Berger, P. L. 1967. The sacred canopy. New York: Anchor Books.

Berger, P. L., \& Luckmann, T. 1966. The social construction of reality. London: Pcnguin.

Biggart, N. W., \& Delbridge, R. 2004. Systems of exchange. Academy of Management Reviez, 29: $28-49$.

Biggart, N. W., \& Guillen, M. 1999. Developing difference: Social organization and the risc of the auto industrics in South Korca, Taiwan, Spain, and Argentina. American Sociological Revieze, 64: 722-747. 
Boisot, M. 1995. Information space. London: Routledge.

Bond, M. H. 1996. Chincsc valucs. In M. H. Bond (Ed.), The handbook of Chinese psychology: 208-226. Hong Kong: Oxford University Prcss.

Bond, M. H., Lcung, K., Au, A., Tong, K., de Carrasqucl, S. R., Murakami, F., ct al. 2004. Culturc-level dimensions of social axioms and their correlates across 41 countrics. Jourmal of Cross-Cultural Psychology, 35: 548-570.

Boyacigiller, N., \& Adlcr, N. J. 1991. The parochial dinosaur: Organizational science in a global contcxt. Academy of Management Review, 16: 262-290.

Boyacigiller, N. A., Kleinberg, M. J., Phillips, M. E., \& Sackman, S. A. 1996. Conceptualizing culture. In B. J. Punnctt \& O. Shenkar (Eds.), Handbook for international management research: 157-208. Cambridge, MA: Blackwell.

Casimir, G., \& Li, Z. 2005. Combinative aspects of leadership style: A comparison of Australian and Chincse followers. Asian Business and Management, 4: 271-291.

Chen, F. 2006. Privatization and its discontents in Chincse factories. The China Quarterly, 185: $42-61$.

Chen, X.-P., \& Chen, C. C. 2004. On the intricacies of the Chinese guanxi: A process model of guanxi development. Asia Pacific Journal of Management, 21: 305-324.

Cheng, B.-S., Chou, L.-F., \& Farh, J.-L. L. 2006. Do employees' authoritarian values matter?: Effectiveness of people vs. task-oriented authoritarian leadership in China and Taizean private business. Symposium panel paper presented at the conference of the International Association for Chinese Management Research, Nanjing, June 2006.

Child, J. 1981. Culture, contingency and capitalism in the cross-national study of organizations. In L. L. Cummings \& B. M. Staw (Eds.), Research in organizational behaviour, 13: 303-356. Greenwich, CT: JAI Press.

Child, J. 2000. Theorizing about organization cross-nationally. In J. L. C. Cheng \& R. B. Pcterson (Eds.), Advances in international comparative management, 13:27-75. Stanford, CN: JAI Press.

Child, J., \& Rodrigues, S. B. 2005. The internationalization of Chinese firms: A case for theoretical cxtension? Management and Organization Review, 1: 381-410.

Chow, I. H.-S. 2004. Human resource management in China's township and village enterpriscs: Change and development during the economic reform cra. Asia Pacific Joumal of Human Resources, 42: 318-335.

Coser, L. 1984. Introduction. In E. Durkheim (Ed.), The division of labour in society: ix-xxiv. New York: The Free Press.

Diamant, N. J., Lubman, S. B., \& O'Brien, K. J. (Eds.). 2005. Engaging the laze in China. Stanford: Stanford University Press.

Dickson, B. J. 2003. Red capitalists in China: The party, private entrepreneurs, and prospects for political change. New York: Cambridge University Press.

DiMaggio, P., \& Zukin, S. 1990. Structures of capital: The social organization of economic life. Cambridge: Cambridge University Press.

Ding, D. Z., \& Warncr, M. 2001. China's labour-management systcm reforms: Breaking the 'three old irons' (1978-1999). Asia Pacific Journal of Management, 18: 315-334.

Ding, X. L. 2000a. Systemic irregularity and spontaneous property transformation in the Chinese financial systcm. The China Quarterly, 163: 655-676.

Ding, X. L. 2000b. The illicit asset stripping of Chinese state firms. The China Joumal, 43: 1-28.

Dolles, H. 2003. Evolution and status of China's private entrepreneurship: An economic actors' perspective. Paper presented at the Euro-Asia Management Studics Association 20th Annual Conference, Stockholm University School of Business, Oct. 2003.

Dore, R. 2000. Stock market capitalism: Welfare capitalism. Oxford: Oxford University Press.

Droege, S., \& Johnson, N. B. 2007. Broken rulcs and constrained confusion: Toward a theory of mcso-institutions. Management and Organization Revieze, 3: 81-104.

Eiscnstadt, S. N. 1968. The Protestant Ethic in an analytical and comparative framework. In S. N. Eisenstadt (Ed.), The protestant ethic and modernization: A comparative vieze: 1-26. New York: Basic Books.

Eiscnstadt, S. N. 1996. Japanese civilization. Chicago, IL: University of Chicago Press.

Etzioni, A. 1988. The moral dimension: Tozvards a neze economics. Ncw York: The Frcc Press. 
Farrell, D., Gersch, U. A., \& Stevenson, E. 2006. The valuc of China's emerging middle class. McKinsey Quarterly, Spccial cdition: 60-69.

Feng, Y., \& McDonough, E. F. 2006. An investigation of the performance appraisal process in Chinese companies versus US based MNCs. Paper presented at the Intcrnational Association for Chincsc Management Rescarch Annual Conference, Nanjing, June 2006.

Fcuchtwang, S. (Ed.). 2004. Making place: State projects, globalization and local responses in China. London: UCL Press.

Fligstcin, N. 2001. The architecture of markets. Princeton, NJ: Princcton University Press.

Fostcr, G. M. 1967. Peasant socicty and the image of limited good. In J. M. Potter, M. N. Diaz, \& G. M. Foster (Eds.), Peasant society: 300-323. Boston, MA: Little Brown.

Friedland, R., \& Alford, R. R. 1991. Bringing socicty back in: Symbols, practices and institutional contradictions. In W. W. Powell \& P. J. DiMaggio (Eds.), The neze institutionalism in organizational analysis: $232-266$. Chicago, IL: Univcrsity of Chicago Press.

Fukuyama, F. 1995. Trust: The social virtues and the creation of prosperity. Ncw York: The Frec Press.

Gecrtz, C. 1973. The interpretation of cultures. New York: Basic Books.

Gelfand, M. J., Nishii, L. H., \& Raver, J. L. 2007. On the nature and importance of cultural tightness-looseness. Cornell Centre for Advanced Human Resource Studics Working Paper Serics: 07/05. Ithaca, NY.

Giddens, A. 1984. The constitution of society. Berkeley, CA: University of California Press.

Gilboy, G. T. 2004. The myth behind China's miraclc. Foreign Affairs, 83(4): 33-48.

Glover, L., \& Wilkinson, A. 2007. Worlds colliding: The translation of modern management practices within a UK based subsidiary of a Korean-owned MNC. Intermational Journal of Human Resource Management, 18: 1437-1455.

Gold, T., Guthrie, D., \& Wank, D. (Eds.). 2002. Social connections in China: Institutions, culture, and the changing nature of Guanxi. Cambridge: Cambridge University Press.

Goodman, D. S. G. 2007. Narratives of change: Culture and local cconomic development. In B. Krug \& H. Hendrischkc (Eds.), The Chinese economy in the 21st century: Enterprise and business behaviour: 175-201. Cheltenham: Edward Elgar.

Greif, A. 1994. Cultural beliefs and the organization of society: A historical and theoretical reflection on collcctivist and individualist socictics. Joumal of Political Economy, 102: 912-950.

Grcif, A. 2006. Institutions and the path to the modern economy. Cambridge: Cambridge University Press.

Guillen, M. F. 1994. Models of management: Work, authority and organization in a comparative perspective. Chicago, IL: University of Chicago Press.

Guillen, M. F. 200l. The limits of convergence. Princeton, NJ: Princcton University Press.

Guthrie, D. 1999. Dragon in a three-piece suit. Princeton, NJ: Princcton University Press.

Guthrie, D. 2006. China and globalization. New York: Routledge.

Hall, P. A., \& Soskicc, D. (Eds.). 2001. Varieties of capitalism. Oxford: Oxford University Press.

Hamilton, G. G. 1990. Patriarchy, patrimonialism and filial piety: A comparison of China and Westcrn Europc. British Journal of Sociology, 41: 77-104.

Harrison, L. E. 1985. Underdevelopment is a state of mind: The Latin American case. Cambridge, MA: Harvard University Centre for International Affairs.

Harrison, L. E. 2006. The central liberal truth. New York: Oxford University Press.

Hendrischke, H. 2007. Networks as business networks. In B. Krug \& H. Hendrischke (Eds.), The Chinese economy in the 21st century: Enterprise and business behaviour: 202-221. Cheltenham: Edward Elgar.

Himmelfarb, G. 2004. The roads to modernity. Ncw York: Alfred A. Knopf.

Hofstede, G. 1980. Culture's consequences. London: Sage.

Hofstede, G. 1991. Cultures and organizations: Software of the mind. London: McGraw-Hill.

Hollingsworth, J. R., \& Boycr, R. (Eds.). 1997. Contemporary capitalism: The embeddedness of institutions. Cambridgc: Cambridge University Prcss.

Housc, R. J., Hanges, P.J., Javidan, M., Dorfman, P. W., \& Gupta, V. 2004. Culture, leadership and organizations: The globe study of 62 societies. Thousand Oaks, CA: Sage.

Huang, D. D. H. 2004. Civil society as an analytic lens for contemporary China. China: An International Journal, 2: 1-27 
Huang, X., Van der Vlicrt, E., \& Van der Vegt, G. 2005. Breaking the silence culture: Stimulation of participation and cmploycc opinion withholding cross-nationally. Management and Organization Reviere, 1(3): 459-482.

Inglchart, R. 1997. Modemization and postmodemization: Cultural, economic and political change in 43 societies. Princeton, NJ: Princeton University Press.

Inglehart, R. 2000. Culturc and democracy. In L. E. Harrison \& S. P. Huntington (Eds.), Culture matters: 80-97. New York: Basic Books.

Inglchart, R., \& Wclzcl, C. 2005. Modernization, cultural change, and democracy. Cambridge: Cambridge University Press.

Jia, L., Zhang, J., Qian, H., Cui, R., \& Chen, Y. 2006. A study on the similarities and differences between the cognitions of Western theories and Chinese enterprises on motivations, timing and industrial choice of enterprises' diversification. Paper presented at the International Association for Chinese Management Rescarch Annual Conference, Nanjing, June 2006.

Kerr, C. 1983. The future of industrial societies. Cambridge, MA: Harvard University Press.

Kerr, C., Dunlop, J. T., Harbison, F. H., \& Myers, C. A. 1960. Industrialism and industrial man. Cambridge, MA: Harvard University Press.

Kogut, B. 2003. Opening address: Context in international business theory. JIBS First Annual Conference on Emerging Research Frontiers in International Business, Duke University, June 2003.

Kong, S.-H. 2006. An empirical investigation of mainland Chinese organizational ideology. Asian Business and Management, 5: 357-378.

Kotter, J. P. 1982. The general managers. New York: The Frec Press.

Krug, B., \& Kuilman, J. 2007. Whom are we dealing with? Shifting organizational forms in China's busincss scctor. In B. Krug \& H. Hendischke (Eds.), The Chinese economy in the 21st century: Enterprise and business behaviour: 223-244. Cheltenham: Edward Elgar.

Landes, D. 1998. The zeealth and poverty of nations. New York: Norton.

Lcung, K., \& Bond, M. H. 2004. Social axioms: A model for social beliefs in multi-cultural perspectivc. Advances in Experimental Social Psychology, 36: 119-197.

Li, P. P. 2005. The puzzle of China's township-village enterprises: The paradox of local corporatism in a dual-track cconomic transition. Management and Organization Revieze, 1: 197-224.

Lieberthal, K., \& Lieberthal, G. 2003. The great transition. Harvard Business Reviez, October 2003: 3-14.

Lu, L., Leung, K., \& Koch, P. T. 2006. Managerial knowledge sharing: The role of individual, interpersonal and organizational factors. Management and Organization Revieze, 2: 15-42.

Lo, V. I., \& Tian, X. 2005. Laze and investment in China. London: RoutledgeCurzon.

Lu, L., \& Alon, I. 2003. Changing cultural and cconomic values of the young and educated in China. Asia Pacific Joumal of Economics and Business, 7(2): 37-52.

Luo, J.-D. 2005. Particularistic trust and general trust: A network analysis in Chinese organizations. Management and Organization Reviewe, 1: 437-458.

McCloskcy, D. N. 2006. The bourgeois virtues: Ethics for an age of commerce. Chicago, IL: University of Chicago Prcss.

Macpherson, C. B. 1962. The political theory of possessive individualism: Hobbes to Locke. Oxford: Oxford University Press.

Mcycr, M. W., \& Lu, X. 2005. Managing indefinite boundarics: The strategy and structure of a Chincse busincss firm. Management and Organization Revieze, 1: 57-86.

Mintzberg, H. 1973. The nature of managerial zeork. New York: Harper and Row.

Nec, V., \& Cao, Y. 2005. Market transition and the firm: Change and income incquality in urban Cihina. Management and Organization Revieze, 1: 23-56.

Nolan, P. 2004. Transforming China: Globalization, transition and development. London: Anthem Press.

Norris, P., \& Inglehart, R. 2004. Sacred and secular: Religion and politics zoorldzvide. Cambridgc: Cambridgc University Press.

North, D. C. 1991. Institutions, institutional change, and economic performance. Cambridgc: Cambridgc University Press.

North, D. C. 2005. Understanding the process of economic change. Princcton, NJ: Princeton University Press. 
OECD (Organisation for Economic Co-operation and Development). 2005. China. Paris: OECD.

Ong, L. 2006. The political economy of township government debt, township enterprises and rural financial institutions in China. The China Quarterly, 186: 377-400.

Pomcranz, K. 2000. The great divergence: China, Europe, and the making of the modem world. Princeton, NJ: Princeton University Press.

Ragin, C. C. 2000. Fuzzy-set social science. Chicago, IL: University of Chicago Press.

Ralston, D. A., Holt, D. H., Terpstra, R. H., \& Cheng, Y. K. 1997. The impact of national culture and economic ideology on managerial work values: A study of the US, Russia, Japan, and China.Joumal of International Business Studies, 28: 177-207.

Ralston, D. A., Pounder, J., Lo, C. W. H., Wong, Y.-Y., Egri, C. P., \& Stauffer, J. 2006. Stability and change in managerial work values: A longitudinal study of China, Hong Kong, and the U.S. Management and Organization Review, 2: 67-94.

Rappai, M. V. 2006. From market to social harmony. China Report, 42: 297-303.

Rawls, J. 1999. Collected papers. Cambridge, MA: Harvard University Press.

Redding, G. 1990. The spirit of Chinese capitalism. New York: de Gruyter.

Redding, G. 1994. Comparative management theory: Jungle, zoo, or fossil bed. Organization Studies, 15: 323-360.

Redding, G. 2005. The thick description and comparison of societal systems of capitalism. Joumal of International Business Studies, 36: 123-155.

Redding, G., \& Witt, M. A. 2007. The future of Chinese capitalism. Oxford: Oxford University Press.

Roberts, K. H. 1970. On looking at an elephant: An evaluation of cross-cultural research related to organization. Psychological Bulletin, 74: 327-350.

Rosen, D. H. 2006. Comparative disadvantage: What China can't do. China Economic Quarterly, Q3: 45-51.

Rosen, S. 2004. The victory of materialism: Aspirations to join China's urban moneyed classes and the commercialization of education. The China Journal, 51: 27-51.

Sato, H. 2003. The grozeth of market relations in post-reform rural China. London: RoutledgeCurzon.

Schluchter, W. 198I. The rise of zestern rationalism: Max Weber's developmental history. Berkeley, CA: University of California Press.

Schumpeter, J. A. 1976. Capitalism, socialism and democracy. London: Routledge.

Schwartz, S. H. 1994. Beyond individualism/collectivism: Ncw cultural dimensions of values. In U. Kim, H. C. Triandis, C. Kagitcibasi, S. C. Choi, \& G. Yoon (Eds.), Individualism and collectivism: Theory, method and applications: $85-122$. Newbury Park, CA: Sage.

Sorge, A. 2005. The global and the local: Understanding the dialectics of business systems. Oxford: Oxford University Press.

State Council of China. 2005. China's peaceful development road. Government white paper. Beijing.

Stiglitz, J. E. 2002. Globalization and its discontents. London: Penguin.

Stinchcombe, A. L. 1974. Creating efficient industrial administration. New York: Acadenic Press.

Strecck, W. 1997. Beneficial constraints: On the economic limits of rational voluntarism. In J. R. Hollingsworth \& R. Boyer (Eds.), Contemporary capitalism: 197-219. Cambridge: Cambridge University Press.

Studwell, J. 2002. The China dream. London: Profile Books.

Sung, Y.-W. 2005. The emergence of greater China. New York: Palgrave Macmillan.

Tam, S. 2001. The nature of entrepreneur-environment relations: A participant reconstruction perspective. Hong Kong University School of Business Working Papers 01-07. Hong Kong University, Hong Kong.

Tang, J., \& Ward, A. 2003. The changing face of Chinese management. London: Routledge.

Tenev, S. 2006. China's ownership transformation. Far Eastern Economic Revieve, 169(1): $22-25$.

Triandis, H. C. 1992. Cross-cultural industrial and organizational psychology. In M. D. Dunncttc (Ed.), Handbook of industrial and organizational psychology, 4: 103-172. Palo Alto, CA: Consulting Psychologists Press.

Tsai, K. S. 2002. Back-alley banking: Private entrepreneurs in China. Ithaca, NY: Corncll University Press. 
Tsui, A. S., Wang, D., \& Zhang, Y. 2002. Employment relationships with Chincse middle managers: Exploring differences between State-owned and non State-owned firms. In A. S. Tsui \& C.-M. Lau (Eds.), The management of enterprises in the People's Republic of China: 347-374. Boston, MA: Kluwer Academic.

Tsui, A. S., Nifadkar, S., \& Ou, Y. 2007. Cross-national cross-cultural organizational behavior rescarch: Advances, gaps and rccommendations. Joumal of Management, 33: 426-478.

UNDP (United Nations Development Programme). 2008. Human Development Report 2007/08 - fighting climate change, human solidarity in a divided world. New York: Palgrave Macmillan.

Wcber, M. 1922. Wirtschaft und Gesellschaft [Economy and society]. Tubingen: J.C.B. Mohr.

Wcber, M. 1927. General economic history (F. H. Knight, Trans.). New York: Grcenbcrg.

Wcbcr, M. 1930. The protestant ethic and the spirit of capitalism (T. Parsons, Trans.). London: Unwin.

Wederman, A. 2004. Great disorder under heaven: Endemic corruption and rapid growth in contcmporary China. The China Revieze, 4(2): 1-32.

Whitley, R. 1992. Business systems in East Asia. London: Sage.

Whitley, R. 1999a. Divergent capitalisms. Oxford: Oxford University Press.

Whitley, R. 1999b. Competing logics and units of analysis in the comparative study of economic organization. International Studies of Management and Organization, 29(2): 113-126.

Whitley, R. (Ed.). 2002. Competing capitalisms: Institutions and economies. 2 Vols. Cheltenham: Edward Elgar.

Williamson, O. E. 1994. Transaction cost economics and organization theory. In N. J. Smelser \& R. Swedberg (Eds.), The handbook of economic sociology: 77-107. Princeton, NJ: Princeton University Press.

Witt, M. A. 2006. Changing Japanese capitalism. Cambridge: Cambridge University Prcss.

Yang, K.-S. 1986. Chinese personality and its change. In M. H. Bond (Ed.), The psychology of the Chinese people: 106-170. Hong Kong: Oxford University Press.

$\mathrm{Y}_{\mathrm{u}}$, B. B., \& Egri, C. P. 2005. Human resource managcment practices and affective organizational commitment: A comparison of Chinese employees in a state-owned enterprise and a joint venturc. Asia Pacific Joumal of Human Resources, 43: 332-360.

Zhang, X., \& Reinmocller, P. 2007. Foreign firms in China: Success by strategic choices. In B. Krug \& H. Hendrischkc (Eds.), The Chinese economy in the 21st century: Enterprise and business behaviour: 42-70. Cheltenham: Edward Elgar.

Zhu, C. J. 2005. Human resource management in China. London: Routlcdgc.

Gordon Redding (gordon.redding@insead.edu) is the recipient of the 2006 IACMR Distinguished Contribution Award. He is Senior Professor of Asian Business and Comparative Management at INSEAD and has spent seven years as Director of the Euro-Asia and Comparative Research Centre there. Previously, he spent 24 years at the University of Hong Kong where he was founding director of its business school. His Ph.D. is from Manchester Business School. His research interest is in the comparison of systems of capitalism.

Manuscript received: December 1, 2006

Final version accepted: March 13, 2008

Accepted by: Kwok Leung 